
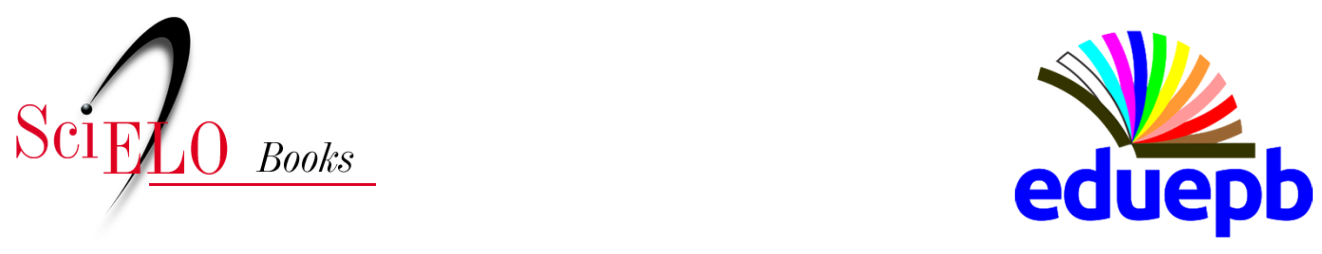

\title{
Influências e Legados \\ Tania Bacelar - Celso Furtado: um intelectual com o pé no chão
}

João Morais de Sousa

Andrea Carla de Azevêdo

\section{SciELO Books / SciELO Livros / SciELO Libros}

SOUSA, J. M. and AZEVÊDO, A. C. Tania Bacelar - Celso Furtado: um intelectual com o pé no chão. Interviewed: Manelito Vilar. In: SOUSA, C. M., THEIS, I. M., and BARBOSA, J. L. A., eds. Celso Furtado: a esperança militante (Depoimentos): vol. 2 [online]. Campina Grande: EDUEPB, 2020, pp. 247-269. Projeto editorial 100 anos de Celso Furtado collection. ISBN: 978-65-86221-11-4. https://doi.org/10.7476/9786586221671.0011.

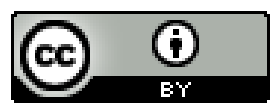

All the contents of this work, except where otherwise noted, is licensed under a Creative Commons Attribution 4.0 International license.

Todo o conteúdo deste trabalho, exceto quando houver ressalva, é publicado sob a licença Creative Commons Atribição 4.0.

Todo el contenido de esta obra, excepto donde se indique lo contrario, está bajo licencia de la licencia Creative Commons Reconocimento 4.0. 


\section{Tania Bacelar}

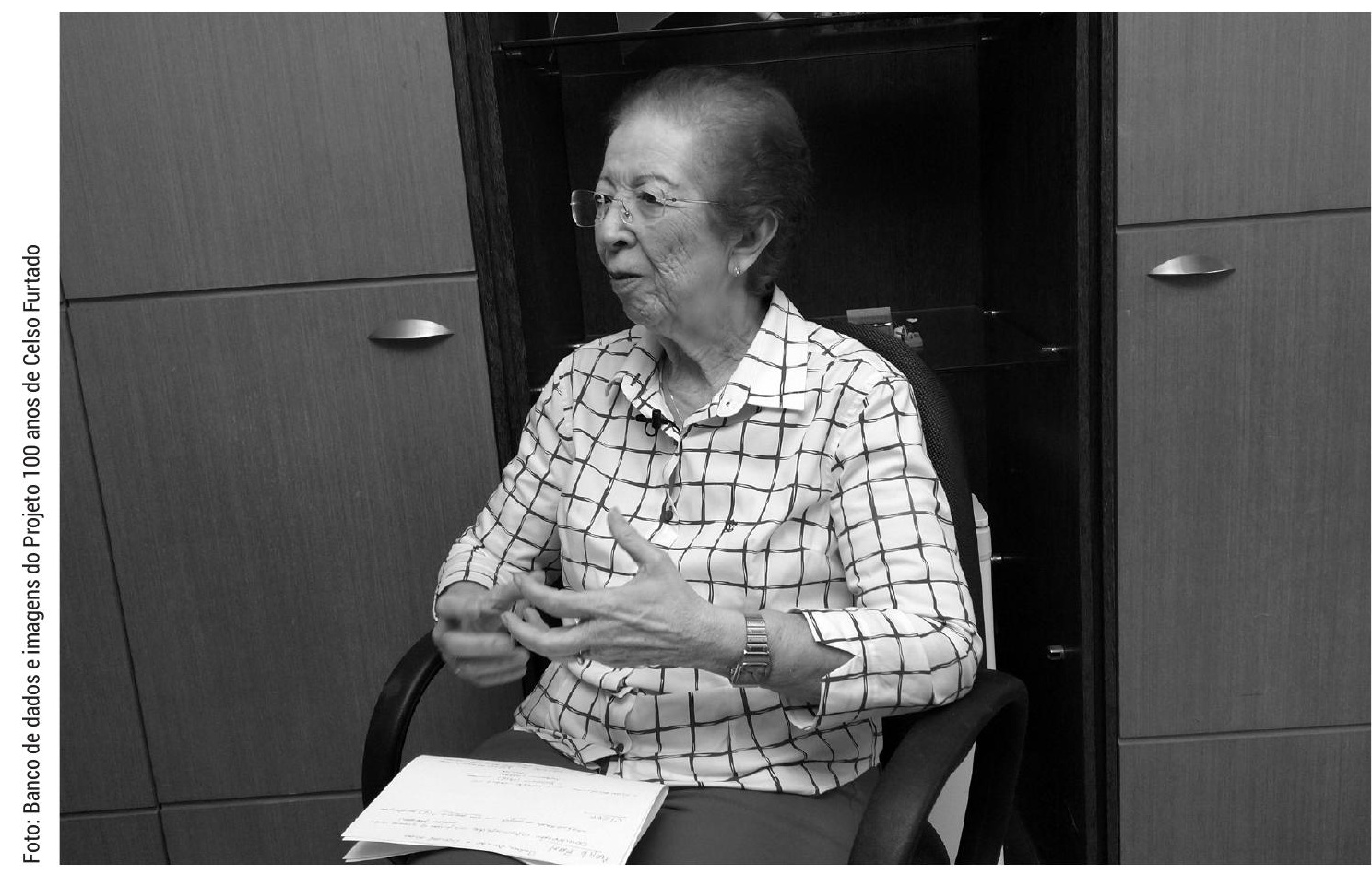

4

Quando se fala em Furtado, eu acho que tem uma característica que é a do intelectual com o pé no chão. Ele sempre me passou isso. "A realidade precisa estar junto de mim". Ele não é um intelectual que só produz por deleite pessoal ou para 0 avanço da ciência. Ele mete a mão na massa, trabalha com a realidade e que quer mudar a realidade. 


\section{Celso Furtado: um intelectual com o pé no chão}

João Morais de Sousa1

Andrea Carla de Azevêdoz

Professora Tania Bacelar de Araújo é pernambucana do Recife.
do Espatorou-se em Economia Pública, Planejamento e Organização Tem mestrado pela mesma Universidade em Política e Programação do Desenvolvimento (1977). Possui graduação em Ciências Sociais pela Faculdade Frassinetti do Recife (1966) e em Ciências Econômicas pela Universidade Católica de Pernambuco (1967). Exerceu vários cargos públicos. Iniciou-se com atuação destacada no quadro de técnicos da Sudene (1966 a 1995) em áreas de economia e planejamento, principalmente para as causas do Nordeste. Depois, atuou como assessora técnica do Ministério do Desenvolvimento Agrário, professora visitante da Ecole des Hautes Etudes em Sciences Socieales, da França. Foi, também, Secretária Nacional de Políticas Regionais e Coordenadora do Grupo de Trabalho Interministerial e encarregada de propor a recriação da Sudene e Sudam (2003). Além disso, atuou como Secretária de Planejamento, Urbanismo e Meio Ambiente do Recife, Diretora do Departamento de Economia da Fundação Joaquim Nabuco e Secretária da Fazenda do Estado de Pernambuco.

A professora Tania Bacelar é sempre lembrada pela forma desprendida, generosa e dedicada à formação. Orientou dezenas de alunos

1 Sociólogo, doutor em Sociologia e Professor Associado do Departamento de Ciências Sociais da UFRPE. Publicou livros e artigos sobre coronelismo, poder local, ensino de ciências sociais, o universo da seca, turismo e educação. Estuda, atualmente, as relações entre arte, cultura popular, cidadania e desenvolvimento sustentável.

2 Jornalista, Mestra em Desenvolvimento Regional pela Universidade Estadual da Paraíba - UEPB (2012); Doutora em Planejamento Urbano e Regional pela Universidade Federal do Rio de Janeiro - IPPUR/UFRJ (2017); Doutora em Governação, Conhecimento e Inovação pela Universidade de Coimbra - FEUC/UC/ COTUTELA, Portugal (2018). Atualmente está como Investigadora Visitante em Estágio Pós-Doutoral no Centro de Estudos Sociais, na Universidade de Coimbra. 
no mestrado e doutorado na UFPE. E participou de outras dezenas de bancas de graduação e pós-graduação. Incansavelmente, sempre aceitou todos os convites. Mesmo com a agenda lotada, sempre encontrou um jeito para participar de abertura de semestres, de semanas acadêmicas de diferentes cursos e, inclusive, eventos organizados pelos alunos. Ela atende a todos como o mesmo encanto e determinação. Ao longo de sua trajetória acadêmica, no Departamento Geografia da UFPE, participou de vários congressos, fóruns, seminários, encontros, colóquios, conferências (nacionais e internacionais), discutindo temáticas como a do desenvolvimento do Brasil, do planejamento regional e das políticas públicas para o desenvolvimento regional.

Essas temáticas estão registradas na sua intensa e qualificada produção acadêmica. São dezenas de livros, artigos em revistas e periódicos nacionais e internacionais, artigos em jornais e documentários. Ao longo de sua trajetória acadêmica lecionou várias disciplinas como: Formação Econômica e Territorial do Brasil, Estado e Economia, Estado e Políticas Públicas, Estado e Políticas Regionais, Analise Regional, Análise e Planejamento Regional.

Como reconhecimento a sua trajetória pública, Tania Bacelar recebeu dezenas de prêmios, entre eles: Título de Doutora Honoris Causa pela Universidade Católica de Pernambuco (2019); Título de Professora Emérita pela UFPE (2019); Prêmio Personalidade Econômica de Ano pelo COFECON (2018);Título de Cidadã Piauiense pela Assembleia Legislativa do Piauí (2016); Ordem do Mérito dos Guararapes - Grã Cruz, Governo do Estado de Pernambuco (2012); Economista do Ano - Setor Público, Ordem dos Economistas do Brasil (2009); Ordem Nacional do Merito Cientifico classe Comendador, Ministério da Ciência e Tecnologia (2004); Medalha do Merito Nilo Coelho, Tribunal de Contas do Estado de Pernambuco (1997).

Atualmente é professora aposentada da Universidade Federal de Pernambuco, mas continua a desenvolver atividades na pós-graduação e no apoio institucional à gestão universitária. Também desenvolve atividades na CEPLAN (Consultoria Econômica e Planejamento).

Tania Bacelar é considerada, por muitos estudiosos, como herdeira de Celso Furtado no que tange a sensibilidade de pensar políticas públicas e estratégias de planejamento e desenvolvimento regional, sobretudo, para a região Nordeste. Na tarde do dia 04 de março de 2020 , em Recife, ela recebeu a nossa equipe, de forma terna e afável, em seu 
escritório, na CEPLAN, para esta entrevista sobre o legado de Celso Furtado. Foi uma entrevista leve, esclarecedora e esperançosa. ${ }^{3}$

Quando perguntada sobre a influência de Celso Furtado em sua trajetória profissional e de vida ela destacou o exemplo do "intelectual com o pé no chão", no sentido de que a realidade não é para estar distante do estudioso, do planejador. A realidade é para está sempre junta e fazer parte desse processo. É para ser transformada. Ela lembra que isso é difícil para quem é da academia. E que Celso Furtado fez isso com maestria. O pensamento dele tem a formulação ancorada em conceitos e em debates teóricos, mas traz junto a leitura da realidade, não só para entendê-la, mas para transformá-la. Assim, seu pensamento tem a realização prática, disse Tania.

Outro legado de Celso Furtado que Bacelar aponta como influência na sua vida foi o do intelectual político. "Isso também é muito difícil para quem é da academia. Ele me inspirou nas várias experiências em que atuei no ambiente político", afirma. Segundo ela, das proposições de Celso Furtado a que mais influenciou na sua formação foi a Sudene, onde começou a trabalhar pouco depois da cassação dos direitos políticos e do exílio do economista. "Se perguntassem a Furtado quais das suas contribuições ele considera a mais importante e simbólica, acredito que ele escolheria a Sudene, uma proposta ousada e muito inovadora para a época. É o principal exemplo de que ele conseguiu entender a realidade para mudá-la", ressalta. Bacelar destaca o capítulo sobre a seca no GTDN como sendo o mais brilhante do mestre. "Furtado inverte o diagnóstico do problema do Nordeste. O problema do Nordeste não era a seca, nem a falta da água, nem as irregularidades das chuvas. Muitos Semiáridos no mundo não tinham os problemas sociais que o Semiárido nordestino apresentava. Ele subverte, assim, o diagnóstico das elites nordestinas que afirmavam que a política pública para resolver este problema teria que ser política hidráulica", pontua. De acordo com Bacelar, Furtado sustentava que o problema não era a seca enquanto fenômeno ambiental, mas as estruturas socioeconômicas organizadas historicamente no Nordeste e como elas condicionam as pessoas e a economia, a exemplo do latifúndio pecuário.

3 Participaram da entrevista, além dos autores: Cidoval Morais de Sousa (coordenador da coleção Celso Furtado: a esperança militante), Andreza Dantas Albuquerque (Pósdoutoranda do PPGDR/UEPB) e o cinegrafista Mahatma Gandhi (ASCOM UEPB). 
Também mostra que a política hidráulica estava errada. Ao invés de resolver se ampliava o problema. Furtado afirmava que não se resolve o problema da falta d'água acumulando água. Tania Bacelar lembra a saída apontada antes pelas elites nordestinas com a criação do DNOCS, e pergunta: acumular água aonde? Os açudes e barragens estavam sendo construídos dentro das grandes propriedades, aumentando o poder dos donos. Furtado compreendeu logo que a grande tragédia da seca era a tragédia social; a tragédia humana.

Para Bacelar, um dos elementos que contribuiu para Furtado se sensibilizar com problemática da seca foi, enquanto sertanejo, ter convivido com uma grande seca, na adolescência. Isso, segunda ela, o politizou, "porque ele queria compreender como era que se dava aquele processo em que pessoas eram obrigadas a viver numa situação de miséria e exploração, inclusive migrando de um lugar pra outro em busca de sobrevivência".

Bacelar lembra, ainda, que o traço principal de Celso Furtado enquanto Intelectual político foi a "ousadia forte". Ele defendia um projeto de mudanças, de transformação da realidade que contrariava o projeto de conservação defendido pelas elites nordestinas. Foi esse traço que, segundo ela, o levou ao exílio. Outra característica de Furtado, na Leitura de Bacelar, era a exímia capacidade de conversar e negociar. "Furtado negociava sem negociar o principal. Ele chegou ao setor público para servir e respeitá-lo, e não para se locupletar"

Quando questionada sobre a Sudene atual, foi pragmática: "é um projeto que ainda não disse a que veio". Quanto a pertinência e atualidade de Furtado como teórico para o entendimento da realidade atual, ressalva que muitas reflexões feitas por ele se referiam a um outro momento histórico do Brasil e do mundo: "O momento atual é portador de outros desafios, como o fenômeno da globalização. Furtado foi um homem do seu tempo, mas foi, também, um intelectual que não se coloca em caixinhas. A abordagem multidisciplinar é o grande desafio da ciência contemporânea. E ele já foi um precursor". Bacelar conclui a entrevista dizendo que sua utopia é ver um mundo sem a desigualdade que se tem hoje, especialmente a regional e humana. Acredita que o mundo tem andado para trás nesse ponto: "a concentração da riqueza é absurda"!

Segue a entrevista na íntegra com o aprofundamento dos pontos citados acima e outras questões. Boa leitura. 


\section{Entrevista}

- Gostaria que a senhora falasse um pouco das suas lembranças e das suas impressões de Celso Furtado.

Conheci de longe, adolescente, quando ele estava na campanha para construir a Sudene. Eu era adolescente, estudante, e a gente começava a conhecer Furtado pelos jornais, debates, ideias. Quando entrei na Sudene, em 1966, ele já estava exilado. Na França, eu fui aluna dele numa disciplina, Teoria do Desenvolvimento. Eu lembro que era uma sala imensa da Sorbonne, um auditório enorme, lotado de africanos e latino-americanos. E ele dando aulas para nós, na época, falando francês com sotaque paraibano. Depois, ele foi da minha banca. Ele não foi meu orientador, ele era de outra unidade na universidade onde eu estudei [Sorbonne], mas eu consegui convidá-lo para a minha banca de defesa da tese de doutorado. Quando ele voltou ao Brasil a gente teve vários momentos de interação, quando ele já estava ministro [da Cultura, do Governo Sarney], em alguns debates, reuniões... então, não foram tantos contatos pessoais.

\section{- Desses momentos, que características a senhora pode destacar do homem Furtado?}

Quando se fala nele, eu acho que tem uma característica que é a do intelectual com o pé no chão. Ele sempre me passou isso. "A realidade precisa estar junto de mim”. Ele não é um intelectual que só produz por deleite pessoal ou para o avanço da ciência. Ele mete a mão na massa, trabalha com a realidade e que quer mudar a realidade. É um traço que o marca. Um intelectual que atua no ambiente político, o que não é muito fácil para quem é da Academia, para quem tem uma produção intelectual, como ele tem, e ao mesmo tempo ter uma atuação no ambiente político. Ele tem essa marca que me sintoniza com ele porque eu também tive experiências no ambiente político, e não é fácil.

Da atuação dele ali no ambiente político eu acho que tem um traço de ousadia muito forte porque o projeto que ele defendia, como eu já disse, era um projeto de mudança, não era de conservação da realidade, mas de transformação da realidade. Eu sempre admirei muito a capacidade dele de negociar. Eu acho que quando você está atuando no espaço político, a capacidade de conversar e de negociar é central. Política, para mim, é conversa. E é construção do que é 
possível fazer naquele momento, né? E para fazer a construção, você tem que negociar. Tem o famoso vídeo sobre Furtado no qual Conceição dá um depoimento que eu achei fantástico. ( $\mathrm{O}$ vídeo) diz que Furtado negociava sem negociar o principal. Eu acho que isso é uma marca importante. Quando se vai para a negociação política você tem que saber até onde pode negociar, e o que é tão importante para o projeto e para as ideias que você está

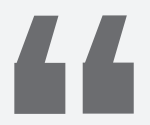

Eu sempre admirei muito a capacidade dele de negociar. Eu acho que quando você está atuando no espaço político, a capacidade de conversar e de negociar é central. Política, para mim, é conversa. E é construção do que é possível fazer naquele momento, né? $\mathrm{E}$ para fazer a construção, você tem que negociar.

defendendo, que é um ponto inegociável. Um exemplo disso que eu sempre dou é a negociação dos incentivos fiscais, que foi uma marca da Sudene e que não era uma proposta de Furtado. Nem no GTDN, nem no primeiro Plano Diretor da Sudene. O artigo 34 foi criado no primeiro Plano Diretor no Congresso. E quem botou o artigo 34 foi um deputado das oligarquias pernambucanas, conservador, que tinha visitado a Itália e tinha visto a experiência lá e trouxe a ideia do modelo dos incentivos para cá e Celso Furtado negociou o artigo 34, que cria o sistema na sua estrutura básica. Você tinha o optante, que é quem iria pagar o Imposto de Renda, mas não vai. Você deve ao Leão mas ao invés de pagar você deposita $50 \%$ do valor no Banco do Nordeste, para financiar projetos. Então era a figura do optante. E você tinha o empreendedor, que era quem iria receber aquele apoio financeiro. Então o modelo, o arcabouço, já estava no artigo 34 e na ideia da criação de um sistema de incentivos para a promoção do desenvolvimento industrial. Na época, era incentivo só para a indústria de transformação. Aí Celso Furtado negocia, o artigo 34 não existia na proposta dele, mas aparece na proposta que foi aprovada pelo Congresso. Foi negociada no Congresso. Aí o artigo 34 tem duas restrições. O sistema é criado, mas o optante não pode ser quem recebe. Era uma negociação. Por que ele faz essa negociação? Porque era para que no Nordeste florescesse um setor industrial de empresários nordestinos. Ele queria patrocinar uma indústria rigorosa no Nordeste, mas que tivesse um protagonismo dos industriais nordestinos importantes. Tinha um sonho político por trás disso, que era substituir, na política, o peso das oligarquias agrárias por 
uma classe empresarial industrial supostamente avançada, ou pelo menos mais avançadas que as oligarquias rurais. Então ele tinha uma visão política por trás da proposta econômica. Ele consegue botar essa cunha: quem opta não é quem recebe os incentivos. A segunda cunha é que tinha que ser empresa nacional, porque ele também tinha um sonho do empresariado local, nacional, então não poderia ser multinacional. Ela poderia renunciar, mas ela não poderia se beneficiar. No artigo 18, depois o sistema passa a se chamar 34/18, já com Celso Furtado fora da Sudene, já no segundo Plano Diretor, em 1965, depois do Golpe. Aí poderia ser qualquer empresa, quem opta pode receber, e pode ser empresa nacional ou multinacional.

\section{- A Sudene de Furtado teria morrido ali?}

Acho que os incentivos morreram ali. Quando ele botou essas duas cunhas, o sistema de incentivos não deslanchou. Ele aceitou a proposta, mas as duas cunhas que ele colocou não viabilizaram o sistema que foi proposto.

\section{- E o que ficou dele?}

O que ficou dele no plano era o essencial. Noventa por cento do primeiro Plano Diretor era a proposta essencial dele na época, investimentos em infraestrutura, no que ele chamava de "pré-condições". Quando a gente lê o primeiro e o segundo Plano Diretor, que foram muito influenciados pelo GTDN, o essencial da ação da Sudene era infraestrutura econômica, de Saúde, Educação, de Pesquisa ... um dos departamentos mais fortes da Sudene no primeiro Plano Diretor era o Departamento de Recursos Naturais. Então 90\% era colado no GTDN. Essa invenção dos incentivos era uma criação ad hoc do que ele tinha proposto, mas foi negociado por ele. Eu acho que esse é um belo exemplo de como você negocia, viabiliza o que você acha que é mais importante, mas aceita o que as outras pessoas estão propondo. Então eu acho que essa marca e importante.

\section{- A senhora falou do intelectual pé no chão, do político que sabia negociar sem abrir mão do principal...}

A terceira [característica] eu diria que é o exemplo de homem público. No Brasil eu acho que a gente é muito carente desse exemplo, de alguém que chega ao setor público respeitando a coisa pública. Não é para se locupletar; é para servir à coisa pública. Se você me 
perguntar de alguém que, no exercício da função pública, para mim é uma referência, é ele. Tem piadas muito interessantes, tem causos muito interessantes, de quem conviveu com ele. Não é o meu caso. Por exemplo: Chico de Oliveira conta histórias de dividir o quarto quando viajava com ele, para não pagar duas diárias. "Pra quê duas diárias? Não tem duas camas no quarto? Nós não podemos dormir no mesmo quarto?" São pequenos gestos que mostram o respeito daquela pessoa ao bem público. O dinheiro é público. Se eu gastar dois, podendo gastar um, eu estou desperdiçando dinheiro público. O pessoal da Sudene inicial tem exemplos cotidianos de lições que ele dava de como lidar com o dinheiro público, respeitando o dinheiro público. Eu acho que no Brasil isso é um exemplo muito importante.

- A senhora disse há pouco que uma coisa que marca o intelectual Furtado 'é o pé no chão’. O pensamento na sua dimensão prática ...

Tem a formulação teórica, mas tem a leitura da realidade e tem o projeto de mudança da realidade. Quando a gente lê Furtado tem sempre as três coisas. Ele está ancorado em conceitos. E tem o lado acadêmico em conceitos, em debates teóricos. Tem a realidade e o acadêmico até ali sempre vai. Mas ele ia mais fundo e dizia: "o conhecimento para mudar a realidade, não só para entender como a realidade é". Tem muito acadêmico que para aí, né? Na Academia, no fazer entender melhor a realidade já é uma contribuição. Mas ele ia além na contribuição. A realidade é assim e poderia ser diferente. Aí já embute o projeto de transformação.

\section{- Das proposições furtadianas, quais a senhora destacaria como} as mais importantes na sua formação?

Na minha, a Sudene. Depois que ele saiu eu trabalhei vários anos na Sudene. Mas eu acho que se perguntasse a ele, das contribuições dele qual ele acharia a mais simbólica, eu acho que ele escolheria a Sudene, também. Acho que é uma proposta ousada, para aqueles tempos, e muito inovadora. Ali é um exemplo que ele conseguiu entender a realidade, e queria mudar a realidade. Pra mim, o capítulo mais brilhante do GTDN é o capítulo sobre a seca. Ele inverte o diagnóstico. Porque até ali o problema do Nordeste era a seca. E ele disse que o problema do Nordeste não é a seca. E nem a seca é o problema do Semiárido. Não é a falta da água nem a irregularidade da água, o 
problema do Semiárido. É que tem muitos Semiáridos no mundo que não tem os problemas sociais que o Semiárido nordestino tinha. Ele subverte, usando uma palavra forte, o diagnóstico das elites nordestinas da época, que o problema do Nordeste era a seca, e que a política pública para resolver era a política hidráulica. Aí ele vai em cima das duas vertentes dominantes. O problema não era a seca enquanto fenômeno ambiental; o problema está nas estruturas socioeconômicas organizadas nesse
4

0 problema não era a seca enquanto fenômeno ambiental; o problema está nas estruturas socioeconômicas organizadas nesse território onde tem as secas. 0 problema não é a ocorrência da irregularidade. Como é que se organizam as pessoas e a Economia, para conviver com esse fenômeno natural? É aí onde está o problema.

território onde tem as secas. O problema não é a ocorrência da irregularidade. Como é que se organizam as pessoas e a Economia, para conviver com esse fenômeno natural? É aí onde está o problema. Ele mergulha fundo onde era o latifúndio pecuário do Semiárido e mostra que a política hidráulica está errada. Ao invés de resolver, ela estava ampliando o problema. Porque é resolver a falta d'água acumulando água. Mas vai botar água onde? Então ele vê que os açudes estão dentro das grandes propriedades, aumentando o poder dos donos. E a grande tragédia da seca era a tragédia social da seca. A tragédia humana. Foi o que politizou Celso. Ele era um sertanejo que conviveu com uma grande seca, na adolescência e se politizou ali. Ele queria entender como é que aquilo acontecia porque as pessoas eram obrigadas a viver numa situação daquela. Então esse capítulo é brilhante porque ele vem com um conhecimento diferente, com uma abordagem diferente, e, politicamente para mim, é o capítulo que marcou a reação política contra ele. A reação política contra ele tem a ver com este diagnóstico, porque fazer o Nordeste industrial muita gente queria. Então o primeiro eixo do GTDN não tinha grandes resistências. Agora o segundo eixo, que era mudar a estrutura econômica do Semiárido, e diversificar a Zona da Mata, encontrou reações enormes contra ele.

\section{- A senhora poderia destacar a importância de Furtado para a sua formação?}

Eu acho que o compromisso dele com o Nordeste. Mas não é com o Nordeste abstrato. É com o Nordeste das pessoas, do nordestino, de 
quem vive aqui. De quem consegue viver aqui. Na época dele, uma grande parte da população nem conseguia viver aqui. Tinha que ir embora para poder viver. Então esse compromisso dele, num intelectual, para mim, é um exemplo incrível. Talvez a identidade do que tem sido um dos meus objetos de estudo que é o Nordeste e alguém que estudou com uma abordagem que me serve de referência, né? Não tem como não servir.

- Problematizando um pouco mais ... Essas mudanças que Furtado faz em relação à interpretação do Nordeste confronta com a concepção do DNOCS, com a proposta do DNOCS? A Sudene de Furtado desempodera o DNOCS?

Com certeza. O DNOCS foi apropriado pelas oligarquias. A proposta dele (Furtado) tirava poder das oligarquias. Ele propunha aumentar o poder dos industriais para diminuir o poder das oligarquias e propunha diversificar a Zona da Mata e reestruturar aquela organização sócio produtiva que existia ali. Então, era muita ousadia junta. Agora o momento que o Brasil vivia não deixava de ser favorável, porque era a era Juscelino, e o Brasil queria ser um exemplo de industrialização no mundo. Acho que isso o beneficiou em estar operando tudo isso num contexto que era muito rico na história do Brasil. Os 50 anos em 5 de JK. Era ali que ele estava operando, né? Não era um Brasil em crise, era um Brasil pungente naquele momento. Claro que muito mais no Sudeste e no Sul, que era elemento de denúncia central dele. "A industrialização é muito boa. Mas é muito boa no Sudeste, e é contra o Nordeste". Ele também denuncia e arranja dificuldades. Mas é muito interessante que na aprovação da lei da Sudene e do primeiro Plano Diretor, não era a elite paulista que era contra. Quem fez estudo de Ciência Política sobre aquele momento mostra que os principais opositores dele eram nordestinos. A bancada conservadora nordestina reagia mais que a elite paulista, que depois se beneficiou da Sudene. Quando o Sistema 34/18 deslancha, Furtado já não estava na Sudene, é que o optante veio a receber o dinheiro. O Brasil já estava naquela fase da Indústria operando em escala nacional. Aí você transbordou as empresas de lá para cá. Eram empresas do Sudeste, empresários do Sudeste que usavam os incentivos para vir para o Nordeste. Então, de certa forma, eles sacaram ali que aquilo não era tão ruim para eles. Então os opositores eram a elite conservadora nordestina. 


\section{- 34/18 teria criado os coronéis urbanos?}

Não, não por isso. Onde o 34/18 funcionou mais parecido com aquela primeira restrição de Furtado foi no Ceará. Tem uma tese de Valdeci [Monteiro dos Santos] ${ }^{4}$ que compara a industrialização no Ceará, em Pernambuco e na Bahia. E você vê que grande parte da indústria no Ceará foi de empresários cearenses. Tanto que no Ceará a classe industrial cearense usou os incentivos, se modernizou e depois tomou o poder. A era Jereissati, a era dos anos 6o, é filha da Sudene. Porque aquilo tem, por trás, uma renovação da produção industrial e o modelo cearense é mais parecido com incentivo fiscal para mudar a estrutura, e criar um pouco do que Celso Furtado queria; uma outra elite industrial, mais progressista. Não é a ARENA, é o PSD. Então é mais parecido o Ceará com o que ele queria do que Pernambuco e Bahia, que são filiais de grandes empresas do Sudeste. E nem aqui nem na Bahia teve uma renovação tão grande da elite industrial, né?

- E o Furtado planejador? A contribuição de Furtado para o planejamento do Brasil? A senhora poderia falar um pouco sobre isso?

É uma contribuição muito importante porque ele acredita no planejamento. A Sudene também era uma instituição de planejamento. Para usar o dinheiro que ele conseguiu, ele fazia um plano. Ele conseguiu que Juscelino criasse uma instituição, e conseguiu o dinheiro, e era muito dinheiro. O arranjo institucional que ele fez na Sudene foi muito ousado. Para mim, uma das coisas mais interessantes que ele fez foi a criação da Sudene. Até porque a Sudene, que depois vingou, era uma estrutura burocrática. A Sudene de Furtado não era uma instituição burocrática, ela era uma instância política. Porque na criação da Sudene de Furtado, mais importante do que a estrutura da Secretaria Executiva, era o Conselho Deliberativo. Então, na cabeça dele, a Sudene era Conselho Deliberativo (CONDEL). Para que o Conselho Deliberativo tomasse uma decisão precisava de uma equipe técnica que subsidiasse essas decisões. Aí precisava de uma estrutura administrativa. E para operar o que fosse decidido, precisava, também, de uma estrutura administrativa. Mas ela não era

4 A Indústria Incentivada no Nordeste: Os Exemplos das RMs de Salvador; Recife e Fortaleza. Dissertação apresentada ao Mestrado em Desenvolvimento Urbano e Regional. Recife: MDU/UFPE, 1994. 
a principal, era auxiliar. O principal era o lócus político de interação, uma coisa ousada, que o Brasil não tem, que é uma instância interfederativa. O pessoal da Ciência Política estuda isso com muita propriedade. Ela é uma instância interfederativa, num país que não tem esta cultura. A cultura é cada um se segmenta. A União é uma coisa, o estado é outra, o município é outra. Aí ele vai e cria um lugar para sentarem todos os governadores com ministros do Governo Federal. Então, aquilo era uma instância decisória interfederativa num país que não tem cultura de gestão interfederativa até hoje. $\mathrm{E}$ a estrutura técnica era uma ordem. Tanto que ele nunca quis fazer prédio. Enquanto ele foi superintendente a Sudene funcionava num prédio alugado e, quando ele voltou [do exílio], o choque que teve foi "parece a sede da ONU!". E dizia: "Isso aqui é sinal de decadência!". Ter aquela estrutura, para ele, era sinal de decadência, desviou-se do que era para ser. Virou uma burocracia. Quem organiza isso é o plano. Aí a defesa do planejamento é central na estratégia dele. E é muito interessante como ele monta as estruturas de planejamento na Sudene. A Assessoria Técnica era a cabeça do planejamento e cada departamento tinha um órgão de planejamento. E aquilo funcionava com um sistema interno de planejamento. E vários programas que ele fazia com os estados, o planejamento era o eixo norteador. Então ele tinha uma célula na Sudene, mas tinha células nos estados para dialogar com o plano. Tudo tinha que primeiro dizer "Nós vamos fazer o que?" "Por que vamos fazer isso?" "Vai gastar quanto?" "Quem é que vai fazer isso?". Então isso é que era o plano. A noção de planejamento é central na proposta dele.

- Em "Brasil: a Construção Interrompida" de 1992, Furtado diz que precisamos saber se temos futuro como nação, que conta na construção do devir humano, ou se prevalecerão as forças que se empenham em interromper o nosso processo histórico e formação de um Estado Nação. Qual é a atualidade do pensamento de Furtado?

Pra mim era uma das obras mais pessimistas de Furtado. Ele não era um pessimista, mas um otimista. Mas aquele livrinho era muito pessimista. Já estava perto de morrer, acho que foi na década de 9o. E "Brasil: a Construção Interrompida" é de um amargor muito grande. São frases muito duras, né? E a ideia é como se o projeto de Brasil tivesse se inviabilizando. Então ele percebe isso. Um momento de ameaça do que foi o projeto de Brasil do século 20. E com todas as 
dificuldades o Brasil tinha se tornado uma potência mundial no século 20. Então tinha uma energia positiva ali no século 20 que deu o Brasil que deu. Era uma potência econômica de pé de barro. Mas aquilo ajudava a construir um projeto de nação. $\mathrm{E}$ tinha um rumo. O Brasil queria ser uma potência industrial, esse era o rumo. E o mundo, na época, era isso. Um mundo que queria ser industrial. Potência era sinal de pungência industrial. Foi isso que o Brasil enga-

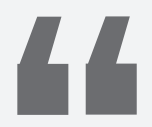

0 Brasil está se desindustrializando porque a Indústria do século 21 não é a Indústria do século 20. E a gente não conseguiu engatar a Indústria brasileira na Indústria do século 21. No século 21 temos uma economia de serviços, a economia do conhecimento. $E$ isso não está na agenda do Brasil, infelizmente.

tou. O problema da gente é como a gente organizou isso do ponto de vista social. E o diagnóstico que ele faz é o mesmo: a gente conseguiu isso, mas tem os pés de barro. E no final do século ele percebe muito bem que parecia que o Brasil estava pegando um desvio. Então aquele livro merece ser lido e refletido, a cada momento, pois ele pára e faz uma espécie de balanço: "fizemos isso, mas não é fácil primeiro construir a nação brasileira. É fácil construir a potência econômica brasileira, mas não basta ser potência econômica para ser uma nação. Para ser uma nação, é preciso que os nacionais se beneficiem do fato de ser potência". Então a dimensão social precisa ser comtemplada. E ali o Brasil estava claudicando, né? Mas era pior. Eu acho que ele já pressentia que o mundo estava mudando e que o Brasil estava perdendo a direção do seu projeto. Porque este é o nosso drama de hoje. Ali, bem ou mal, tinha esta unidade de fazer do Brasil uma potência industrial relevante. Só que a indústria de transformação no mundo foi completamente transformada nas novas tecnologias. Então todo o esforço que a gente fez, está se perdendo. O Brasil está se desindustrializando porque a Indústria do século 21 não é a Indústria do século 20. E a gente não conseguiu engatar a Indústria brasileira na Indústria do século 21. Parece que ele pressentiu ali que a gente tinha dado um passo em falso. Que o mundo estava indo numa direção daquilo que era o miolo do nosso projeto do século 20, que estava terminando, e a pergunta era “Qual é o projeto do século 21?". No século 21 temos uma economia de serviços, a economia do conhecimento. E isso não está na agenda do Brasil, infelizmente. Então a gente nem é mais industrial e está voltando a ser primário exportador e num 
modelo que o mundo também rejeita. O modelo tradicional, conservador, explorador da Natureza. Tudo o que no debate mundial sobre o que é desenvolvimento não é. E o Brasil se firmando como potência agrícola, produtora de soja, produtora de carne a qualquer custo social, a qualquer custo da Natureza. Isso é um horror. Para quem tinha um sonho que a Nação fosse contemporânea, decente. Então aquele livro eu acho que é um sinal de alerta. Se ele tivesse vivido, talvez hoje ele fosse uma das pessoas que pudesse estar refletindo com a gente. "E aí, agora a gente faz o quê?". Mas ali ele pressentiu. Aquilo é um livro fino, mas de uma intensidade enorme.

- A senhora falou da ousadia de Celso Furtado e eu imagino que a elite deve ter esperneado. Juscelino Kubitschek dava cobertura a Celso Furtado nessa ousadia, ou em alguns momentos ele lutou só?

Eu não vivi junto dele neste tempo, né? Eu só entrei na Sudene em 1966 e já não era JK. Neste tempo eu era estudante. Então, na minha vivência, não tenho depoimento sobre isso. Mas, do que eu li de pessoas que conviveram na época, Rômulo de Almeida, Chico de Oliveira, que viveu essa aventura, né? O depoimento central é de que Juscelino apoiava. Agora, Juscelino estava acima dele em outro patamar de negociação. Talvez, em alguns momentos, Juscelino não tenha dado o apoio que ele precisava. Mas o depoimento predominante é que ele [Furtado] contava com JK nas horas essenciais e ele [Juscelino] foi um aliado importante no projeto dele [Furtado]. Mas Juscelino depois entrou em confronto com o projeto mais conservador que existia no Brasil. Tanto que ele também foi defenestrado.

- A gente está falando da atualidade do pensamento de Furtado. $O$ que a senhora destacaria mais para entendermos a realidade de hoje utilizando Furtado como teórico?

Para trazê-lo, hoje, primeiro tem esse desafio que já citei, né? Muitas das reflexões que ele fez eram sobre um outro momento do mundo, e um outro momento do Brasil. Então, se a gente quiser transportar Furtado não é bom errar. Ele raciocinou para um momento que não é o momento que a gente está vivendo. $\mathrm{O}$ momento atual é portador de outros desafios. Estamos precisando de outro Furtado. Estamos precisando de alguém que tenha a capacidade dele, e vários alguéns, porque a bronca é tão séria que não é um alguém que vai dar conta. 
Ele foi um homem do tempo dele, que deu um aporte inovador para os desafios daquele momento. A gente está vivendo um outro momento e temos que ter reflexão nossa, de quem ainda está vivo, para pensar esse novo momento, que não é fácil. Mas tem premissas com as quais ele trabalhou, que eu acho que a gente deve se inspirar nele. Eu não acho que ele deva ser abandonado. Ele continua uma referência, e eu acho que a gente precisa ir nessas referências para pensar o hoje. Por exemplo: a abordagem Multidisciplinar é central em Furtado. Ele não era um economista. Aliás, ele nem fez curso de Economia. Chamam ele de economista. Ele foi advogado e ele era um cientista político e um analista econômico, e era muita coisa. Um homem que estudava Literatura, um profundo conhecedor ... um intelectual. Um intelectual a gente não consegue botar numa caixinha. As caixinhas são da burocracia. Ele é muito mais do que isso. A abordagem Multidisciplinar é o desafio mais contemporâneo até hoje, do que na época dele. Ele já era um precursor. Então a dimensão ambiental, para falar numa [questão] que ele não trabalhou profundamente, porque na época dele não tinha a dimensão que tem hoje. O Aquecimento Global não era agenda da época dele. É uma agenda de hoje que faz com que, para pensar o que ele pensou, para pensar um projeto de desenvolvimento para o Brasil não se pode desconsiderar a dimensão ambiental. E a gente consegue, vasculhando na obra dele, identificar que a leitura dele da seca não é arraigada na dimensão ambiental. Ele diz que a dimensão ambiental existe, é um fator restritivo, mas é a dimensão socioeconômica que precisa mudar. Isso é uma leitura multidimensional, tá certo? A dimensão cultural que está em Furtado. Não é à toa que ele foi ministro da Cultura. E como é que um economista é ministro da Cultura? Não era economista no Ministério da Cultura, era um homem que ao pensar, ao refletir, ao propor, a dimensão cultural estava presente. A dimensão da ciência e tecnologia. A compreensão de que o conhecimento era uma variável estratégica. E se vê na descrição dele em "Formação Econômica do Brasil', como ele lida com a dificuldade que o Brasil carregou no século 20 todo porque não gerou conhecimento próprio, e para fazer os 50 anos em 5 de JK, importou conhecimento. A rapidez fez com que ao invés de o Brasil ser um país em que a indústria já nasce produzindo conhecimento, ela importa máquinas e equipamentos. Mas na reflexão de Furtado você tem a preocupação com a fragilidade que isso importa. Faz ligeiro, mas faz capenga. E faz 
capenga porque a reflexão não veio de dentro. E quando eu importo a máquina eu estou importando uma realidade diferente da minha. E estou num país que tem mais gente do que países avançados que tinham pouca gente, que criaram máquinas para pouca gente. Aqui eu tenho que criar máquina para muita gente. Então essa reflexão é fundamental. Eu acho que tem elementos de Furtado que são referências que a gente não pode dizer não. Ele estudou outro momento e por isso eu não vou visitá-lo?. Eu acho que a gente sempre revisita para ir buscar a substância, onde é que está a contribuição principal para refletir sobre desafios novos. Então novos desafios que a gente tem ... o mercado de trabalho hoje é um novo desafio. Não é só a gente que não consegue acessar. Na época dele as pessoas não conseguiam acessar, e não conseguiam sobreviver. Hoje as pessoas, em sua grande maioria, estão acessando de um jeito completamente diferente. Todo mundo "uberizado", ninguém tem nenhuma referência. Nós estamos subvertendo o mercado de trabalho de um jeito ... no mundo, não é só no Brasil. E no Brasil estamos fazendo isso na dosagem brasileira. São problemas novos, desafios novos que no tempo dele nem passava pelo juízo o que seria, por exemplo, "uberização". Chegar aqui na frente do meu prédio e ter um bando de rapazes e de moças, de moto, de bicicleta com aquelas coisas nas costas. Então é uma coisa nova, que está desafiando os movimentos de organização dos trabalhadores. Você lê as pessoas que estão refletindo sobre o movimento sindical ... aquilo que eles faziam não é mais adaptável. Vai organizar como? Tem perguntas novas, que a gente tem que resolver, e que Furtado nem chegou junto porque não eram questões centrais no tempo dele.

\section{- Qual era a preocupação dele com a formação / educação de seu corpo técnico?}

O tema aí é Furtado e a Educação. Tem muita gente que diz que Celso Furtado não valorizava a Educação. Eu acho que esse tema é muito interessante, Furtado e a Educação. Aí eu vou dar o meu depoimento. Eu entrei na Sudene como auxiliar de pesquisa. Eu fazia dois cursos ao mesmo tempo: Ciências Sociais e Economia. Ciências Sociais à tarde e Economia à noite. Então [como é que], não valorizava a Educação, mas tinha um Departamento de Recursos Humanos? A Sudene de Furtado tinha dois departamentos muito fortes: Recursos Humanos e Recursos Naturais. Quem não pensa em Educação, não 
pensa em gente. É preciso analisar o que era o Departamento de Recursos Humanos. Acho que dava uma tese interessante, "Furtado e a Educação", olhando o que ele fez na Sudene. Muita coisa se perdeu e ninguém sistematizou. Então, para voltar para mim, eu foquei nesse Departamento de Recursos Humanos. E sabe qual era o trabalho? A Sudene era a Capes da época, mas para graduação. Porque naquela época o Nordeste não tinha graduação. Então uma das deficiências do Nordeste era gente qualificada. Para fazer a Sudene foi difícil, tinha que fazer o TDE. Tinha que investir em gente. Você fazia um curso e os melhores qualificados entravam na Sudene. Então, uma pessoa dessa não valorizava a Educação? Como foi que ele recrutou? Não foi com bilhetinho de deputado. Depois [de Furtado] é que virou bilhetinho de deputado. Era fazer o TDE, um curso intensivo de desenvolvimento, e os melhores qualificados iam trabalhar na Sudene. Quando eu entrei na Sudene tinha duas pesquisas precisando de gente: uma em Saúde, onde eu também trabalhei, que era para mapear onde estava a oferta de serviço de saúde, e a outra era o que eu chamo "a Capes da graduação", que era uma bolsa que a Sudene instituiu para estimular os jovens a fazerem curso superior. Dava uma bolsa para o menino sair lá do interior e fazer Geologia, por exemplo, ou escolher um curso daquilo que o Nordeste precisa para se desenvolver. Onde é que estão os especialistas em Geologia, em Mineração? Engenharia de Minas, Economia, Sociologia? Para esses cursos a Sudene dava uma bolsa para a pessoa vir, estudar e terminar a Graduação. Eu conheço muita gente que diz até hoje "Só me formei porque tive a chance de ter aquela bolsa”. Naquela época não tinha Pós Graduação. Pós Graduação a gente fazia no exterior. Era difícil fazer a Graduação! Sabe o que a gente fazia como pesquisador? Ia na casa dos meninos. O candidato à bolsa era fiscalizado. A gente saía numa Rural Willys para visitar a família para ver se realmente aquela pessoa precisava daquela ajuda. Não era uma coisa gratuita. Era uma coisa dada com um objetivo: ela tinha que fazer o curso, mas a gente tinha que ir lá saber se o menino realmente morava num lugar pobre, se a família realmente não tinha condição, se ele realmente era merecedor. Eu fiz essa pesquisa. Eu acho que uma pessoa dessa valoriza Educação. A crítica era "mas não valorizava Educação básica". Aí eu sugiro uma entrevista com quem trabalhou com ele na educação básica. Ele tinha um programa muito interessante de apoio às secretarias de estado, porque a Educação não era do Governo Federal. A 
Educação básica era do Estado e Município. Então, qual era a ideia da Sudene inicial? Era fortalecer as estruturas que ofertam a Educação Básica. Quais são as estruturas? Estaduais e municipais. Teve um programa da Diretoria de Educação que se relacionava com as secretarias de educação para formar gente para fazer o planejamento educacional, para melhorar o ensino básico, onde estava a responsabilidade do ensino básico. Não era para trazer o ensino básico para a Sudene. Era usar o dinheiro da Sudene para qualificar os estados e contribuir para melhorar as estruturas do ensino básico. Então eu acho que aí tem um componente de educação.

\section{- Mais ou menos como era feito com os outros setores...}

Então, a Sudene, com essa visão, de sistema, de articulação dos estados, foi quem montou os NAEs que virou SEBRAE. Foi quem montou as CEPAs, que era a Unidades de Planejamento Agrícolas de todos os estados. Fazia cursos. Eu fui professora de vários cursos. Fazendo o quê? Trazíamos o pessoal que trabalha com agricultura nos estados e fazíamos um curso na Sudene, um curso intensivo. O aluno vinha só para estudar, tinha que ser dedicação exclusiva. Dava-se uma bolsa para complementar a vinda dele para cá, e ainda dava outra quando ele voltava. Para que ele não chegasse no estado, na volta, formado para entrar na CEPA, chegava brilhante, atualizado, e o secretário puxa para ser assessor dele, e não tinha a gratificação que a Sudene dava. Então era uma gratificação para ele montar a unidade para a qual ele tinha sido capacitado. Isso não é pensar Educação? Isso não é formar quadros de conhecimento? Mas acho que esse é um debate porque ele está sendo acusado de não valorizar a Educação.

\section{- E quanto a relação de Furtado com a Cultura?}

Também, não é à toa que ele foi ministro da Cultura. Mas na Sudene de Furtado a valorização da Cultura está na ARTENE, que era uma subsidiária da Sudene para promover o artesanato. Um dos potenciais que ele via no Nordeste vinha da Cultura. E ele criou a ARTENE, que na época dele era uma instituição muito interessante, porque tinha toda uma política de promoção do artesanato. Era uma empresa onde a Sudene tinha uma participação acionária, tinha vida própria, e era de comercialização. Veja que coisa inovadora naqueles tempos! A promoção de um ente que não é somente público, para organizar o grande problema do artesão. E qual é? Ele sabe produzir, mas não 
tem acesso ao mercado. Então, o diagnóstico que ele fez mostra que tem um potencial que vem da Cultura, que é riquíssima, mas o pessoal vive na miséria. E por que vive na miséria? Porque quem ganha dinheiro é quem comercializa, portanto o nó está na comercialização. Aí, ele cria uma agência para organizar a comercialização, para romper com esse ciclo que quem tinha acesso ao mercado era a elite. Ela recebe por $\mathrm{R} \$ 4$ e vende por $\mathrm{R} \$ 30$, ou até por $\mathrm{R} \$ 50$.

\section{- E ele criou outras outras subsidiárias ...}

Várias. Era uma modelo gerencial novo. Ele não queria inchaço mesmo. A Sudene para ele era um negócio enxuto. Era um negócio de organização, de diálogo, mas precisava fazer as coisas. A CONESP, por exemplo. Tinha que perfurar poços onde tivesse que perfurar. Aí ele cria uma empresa para perfurar poços. Mas era um negócio fora da Sudene. Quando cumprisse a missão, acabava. Tanto que ela acabou e já tinha uma empresa para perfurar poço. Não precisava mais do Estado

- Ele estava antecipando o processo de incubação..

Incubava. Incubava para depois soltar, né? E aconteceu isso. Tanto que várias desapareceram e já tinha o dinamismo da própria vida econômica e tinha criado elementos para substituir aquilo. Mas era um modelo de gestão que foi outro ponto interessante, que é pouco estudado. O modelo de governança, como se chama hoje, que estava na cabeça de Furtado era muito inovador para a época.

\section{- Por quanto tempo o pensamento de Furtado conseguiu preva-} lecer na Sudene?

Eu diria que uns 10 anos. Entrei em 1966, e, da minha vivência, eu acho que a semente que ele plantou foi tão bem plantada que ela germinou mesmo num outro contexto, completamente diferente. Já eram generais que dirigiam. Mas eu ouvi de um general que foi superintendente a seguinte frase: "Me disseram que eu iria encontrar aqui um antro de comunistas, mas eu encontrei um antro de idealistas". Era a obra de Furtado. Era o jeito com o qual ele concebeu a instituição. Era um bando de idealistas. Então, eu diria da minha vivência que, os anos meus iniciais ainda estão muito impregnados das ideias dele, das propostas dele. Eram tão ousadas, tão inovadoras que a turma tinha comprado a ideia. Pessoas como Carlos Miranda, que 
vocês entrevistaram, como Otamar, que viveram mais cedo do que eu estavam lá ainda, eram desdobramentos daquelas sementes que ele (Furtado) tinha deixado lá. Quando você planta boa semente, ela não morre, não. Ela vai germinando. Ela pode não germinar do jeito que você queria, mas vai germinando. Uma instituição pública é um ente vivo. Depois vem a Sudene dos incentivos e foi esta que terminou morrendo, né? Então eu acho que tem três fases da Sudene: a fase de Furtado, a fase pós Furtado, já no regime militar, mas onde várias sementes ainda germinavam, e a fase que perde recursos e que fica pendurada nos incentivos, que foi reapropriada pelos interesses da elite. Já é uma Sudene se preparando para morrer. Eu diria que é a Sudene dos anos 8o, por aí.
Quando você planta boa semente, ela não morre, não. Ela vai germinando. Ela pode não germinar do jeito que você queria, mas vai germinando. Uma instituição pública é um ente vivo. Depois vem a Sudene dos incentivos e foi esta que terminou morrendo, né? Então eu acho que tem três fases da Sudene: a fase de Furtado, a fase pós Furtado, já no regime militar, mas onde várias sementes ainda germinavam, e a fase que perde recursos e que fica pendurada nos incentivos, que foi reapropriada pelos interesses da elite. Já é uma Sudene se preparando para morrer. Eu diria que é a Sudene dos anos 80 , por aí.

\section{- E a atual?}

A atual é um projeto. Não disse a que veio.

- O que a senhora acha hoje dos estudos regionais? Do desenvolvimento regional...

Se tem uma coisa nova, que não é da época de Furtado, é o grau de globalização que existe hoje. O grau de globalização que a economia mundial alcançou tem um certo descolamento do território. A lógica da Globalização é uma lógica territorial que não é a lógica com a qual nós, pobres mortais, trabalhamos. Aí tem um certo distanciamento. Mas o que eu vejo é que as nações continuam. As empresas se globalizaram, mas a nações continuam. Então tem uma escala pós-global que ainda é nação. A China, por exemplo, é um projeto de nação. Não é um projeto de globalização abstrato. A China quer ser uma potência mundial e está recuperando a nação. Aliás, no dia em que Mao morreu eu morava na França e eu vi na tv uma frase de um senhor que 
tinha passado pelo caixão de Mao, estava sentado no chão e o repórter chegou perto dele e disse: "O senhor está chorando por quê?" O que foi que Mao legou à China? Ele disse: "Mao recolocou a China de pé". Ele não falou do Socialismo. Ele disse: "Mao recolocou a China de pé”. Veja aí o conceito de nação na frase dessa pessoa. Eu acho que nessa escala de nação, que era uma preocupação de Furtado, a gente não está delirando. Ainda tem um espaço para discutir a consolidação da nação brasileira. Aí eu estou com ele. Agora, dentro da nação, eu hoje vejo os estudos regionais. [Clélio] Campolina está fazendo estudos regionais, é outro maluco, né? E ele foi embora para o mundo para ver como o mundo está tratando isso. E a relação entre os novos modelos de desenvolvimento, e as sub-regiões, é enorme. As políticas regionais hoje não estão fora de moda. Eu não acho que a gente vai perder emprego, não. Eu acho que a gente continua tendo espaço. Agora, é com moldes e desafios diferentes daqueles que a nossa geração trabalhou. Mas eu continuo estimulando meus alunos a não jogar a toalha. Para fazer o que eu não poderei fazer porque os desafios são diferentes. As políticas regionais estão se transformando, se aproximando dessa dimensão de inovações científico-tecnológicas. Têm uma relação muito mais forte hoje de política de inovação e política regional, que não tinha na nossa época. $O$ jeito de fazer as coisas, mudou. Porque o conhecimento humano está mudando. Está mudando até quem faz. Quem vai fazer é a inteligência artificial, o robô ou não sei o quê, que dirá o jeito de fazer. Eu acho que tem um campo novo aí. Não é mais o nosso desafio, não é mais aquela literatura que a gente recomendou. Agora a temática eu acho que é atual. As duas, né? Tanto a consolidação da nação como a dimensão da desigualdade regional. A gente não estuda região só por estudar região. A diversidade regional é um dos nossos temas. Mas a desigualdade regional é um dos nossos temas e ele está atualíssimo. [Vocês] não estão desempregados.

\section{- Sua utopia?}

Minha utopia é um mundo sem a desigualdade que a gente tem hoje. Regional e humana, sobretudo. Eu acho que, nesse ponto, o mundo andou para trás. A gente está num momento do mundo onde a concentração da riqueza é tão absurda, que não cabe todo mundo. E é esse o grande desafio que o Papa Francisco está botando o dedo na ferida. E eu estou com ele. A chamada economia de Francisco Como 
concepção, ainda não está formulada, mas como problema, esse é o problema. As hordas de imigrantes, coisas que a gente está vendo no mundo inteiro. $\mathrm{O}$ mundo tem meios para não ter isso. Então, eu acho que ele está certo. Uma utopia minha é ver se isso dará certo. 